\title{
Comparison Between Kinesio Taping and Extracorporeal Shockwave Therapy in Treatment of Subacromial Impingement Syndrome
}

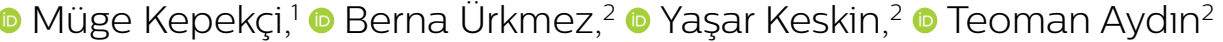

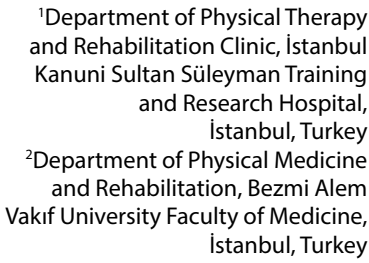

'Department of Physical Therapy and Rehabilitation Clinic, İstanbul Kanuni Sultan Süleyman Training and Research Hospital, İstanbul, Turkey 2Department of Physical Medicine and Rehabilitation, Bezmi Alem Vakıf University Faculty of Medicine İstanbul, Turkey

Submitted: 13.08 .2018 Accepted: 26.11.2018

Correspondence: Müge Kepekçi, Kanuni Sultan Süleyman Eğitim ve Araştırma Hastanesi, Fiziksel Tıp ve Rehabilitasyon Kliniği, İstanbul, Turkey

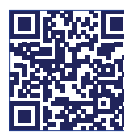

Keywords: Extracorporeal shock wave therapy, kinesio taping; subacromial impingement syndrome.

\begin{abstract}
Objective: The aim of the study was to compare the effects of the kinesio taping (KT) and extracorporeal shock wave therapy (ESWT) methods in the treatment of subacromial impingement syndrome (SIS).

Methods: In the present study, a total of 105 patients with SIS were randomly divided into three groups: active kinesio taping (Group I), sham kinesio taping (Group 2), and extracorporeal shock wave therapy (Group 3). Visual analogue scale (VAS) was used to measure patients' pain, and the disabilities of the arm, shoulder and hand (DASH) score was used to evaluate the degree of functional disorders.
\end{abstract}

Results: No statistically significant difference was determined between the groups with regard to age, gender, marital status, body mass index, and acromion types. Post-treatment VAS scores of Groups I and 3 decreased when compared to baseline VAS scores.

Conclusion: Our study reveals the clinical benefit of KT and ESWT in the treatment of non-calcific tendinitis. They can be suggested as an alternative to conservative treatments according to short-term results.

\section{INTRODUCTION}

Subacromial impingement syndrome (SIS) is the most common cause of shoulder pain. Supraspinatus tendinitis develops due to the impingement of bicipital tendon between the humerus and the coracoacromial arch, as a result of the pressure on subacromial bursa. ${ }^{[1]}$

Neer ${ }^{[2]}$ divided SIS into three pathological stages: edema and hemorrhage, fibrosis and tendinitis, and bone degeneration and tendon ruptures.

The first method of treatment for SIS is conservative. As the conservative treatment, rest, cold application, hot application, electrotherapy modalities, transcutaneous electrical nerve stimulation, ultrasound, phonophoresis, high voltage galvanic stimulation, laser, iontophoresis, cryotherapy, use of nonsteroidal anti-inflammatory drugs, local steroid injection, range of motion exercises, joint mobilization techniques, proprioceptive neuromuscular facilitation techniques, exercises for shoulder and scapular muscles, functional training, and transverse friction massage could be applied.

Some recent studies proposed kinesio taping (KT) and extracorporeal shockwave therapy (ESWT) as alternative conservative treatment options for SIS. ${ }^{[3,4]}$

The purpose of the prospective study was to compare short-term clinical outcomes of KT and ESWT in patients who applied to our clinic with SIS in 2016.

\section{MATERIAL AND METHODS}

\section{Study design}

This study was a prospective randomized controlled study, and it was carried out after an approval by the 
Ethics Committee (7/306642-050.01.04). Patients were informed. This study included 105 patients (Fig. I). The supraspinatus outlet graphy, antero-posterior shoulder graphy, routine blood tests, complete blood count, and biochemistry tests were recorded before the study. The AP shoulder graphy and supraspinatus outlet graphy were repeated after 4 weeks.

\section{Patients}

A total of 105 patients who applied to the Physical Medicine and Rehabilitation Clinic and Orthopedic Clinic with a diagnosis of SIS were randomly divided into three groups with a simple randomization method by using online randomization software (GraphPad Software QuickCalcs).

There were three groups total: an active KT group (Group I), sham KT group (Group 2) and ESWT group (Group 3). Each group received a 4-week therapy program.

Group I: Active KT group patients were asked to come to the clinic a total of 6 times at 5-day intervals for 4 weeks. Each time they came to the clinic, active KT was performed by applying a muscle technique (inhibition) and area correction techniques with the same color "Kinesio Tex Gold" branded tape. Muscles that were found to be injured on the magnetic resonance were evaluated and muscles injuries were identified requiring treatment. The KT muscle inhibition technique for these rotator cuff muscles was applied with a $10 \%$ tension. In addition, kinesio taping mechanical anterior correction techniques were performed on the glenohumeral joint with a $50 \%-75 \%$ tension, and kinesio taping space correction techniques were performed with a $10 \%-20 \%$ tension to the points where pressure decreasing was intended. ${ }^{[3]}$ An exercise program was recommended to all patients. While the size varied from patient to patient, three $Y$ tapes were cut at an average length of $20 \mathrm{~cm}$. The application was started by attaching the thick end of the $Y$ tape without applying any tension on the first 3-4 centimeters, then the arms of the $Y$ tape were attached with a slight tension, and the ends were attached without any tension. The last $Y$ tape was attached to a painful area with an area correction technique, with a maximum tension in the middle and no tension at the ends (Fig. 2).

Group 2: The sham kinesio taping group patients were asked to come to the clinic a total of 6 times at 5-day intervals for 4 weeks. Each time they came to the clinic, a sham KT was performed by applying the muscle technique (inhibition) and area correction techniques with the same color

\begin{tabular}{|c|c|c|}
\hline \multicolumn{3}{|c|}{ Randomized Patients ( $n=189$ ) } \\
\hline & $\begin{array}{l}(n=34) \text { unwillingness } \\
(n=10) \text { inappropriate age } \\
(n=13) \text { cervical pathology } \\
(n=3) \text { breast cancer } \\
(n=22) \text { discontinuance } \\
(n=2) \text { allergic skin reaction }\end{array}$ & Excluded \\
\hline $\begin{array}{c}\text { Group } 1 \\
\text { Active KT } \\
(n=35)\end{array}$ & $\begin{array}{c}\text { Group } 2 \\
\text { Sham KT } \\
(n=35)\end{array}$ & $\begin{array}{c}\text { Group } 3 \\
\text { ESWT KT } \\
(n=35)\end{array}$ \\
\hline
\end{tabular}

Figure 1. Study flow chart.
"Kinesio Tex Gold" branded tape. The tape was attached as an I-tape, without tension and not corresponding to the origin and insertion of the trapezius muscle (Fig. 2).

Group 3: The extracorporeal shockwave therapy group patients received the shock wave therapy at weekly intervals for a total of three treatments. Each patient received ESWT at a frequency of $15 \mathrm{~Hz}$, density of 2.0 Barr and the pulse/ session of 2000. An EMS Swiss DolorClast Master branded ESWT device was used (Fig. 3), and a hot package was used as a superficial heat agent. A month after their first visit, patients were asked to come to the clinic for an evaluation.

In the ESWT application, the medium energy current was delivered with 1200 shocks per session, $2 \mathrm{~Hz}$ frequency, and 120 shocks/minute rate. ${ }^{[5,6]}$ The first treatment was started with $0.03 \mathrm{~mJ} / \mathrm{mm}^{2}$ in low-energy density, and it was increased up to the $0.28 \mathrm{~mJ} / \mathrm{mm}^{2}$ density according to the patient's tolerance.

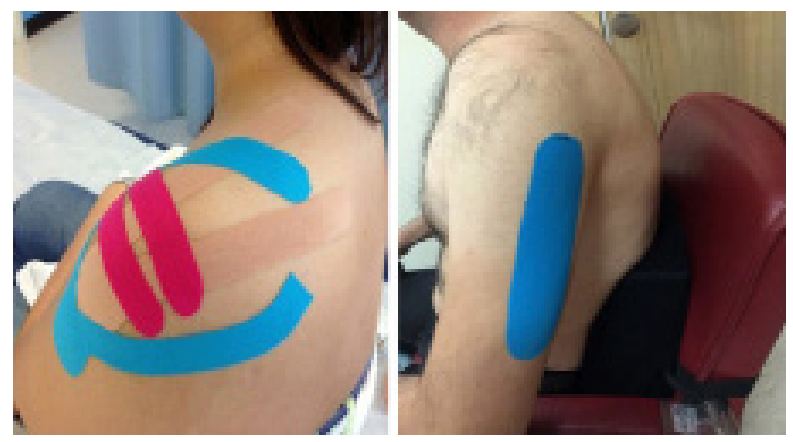

Figure 2. Active kinesio taping-sham kinesio taping.

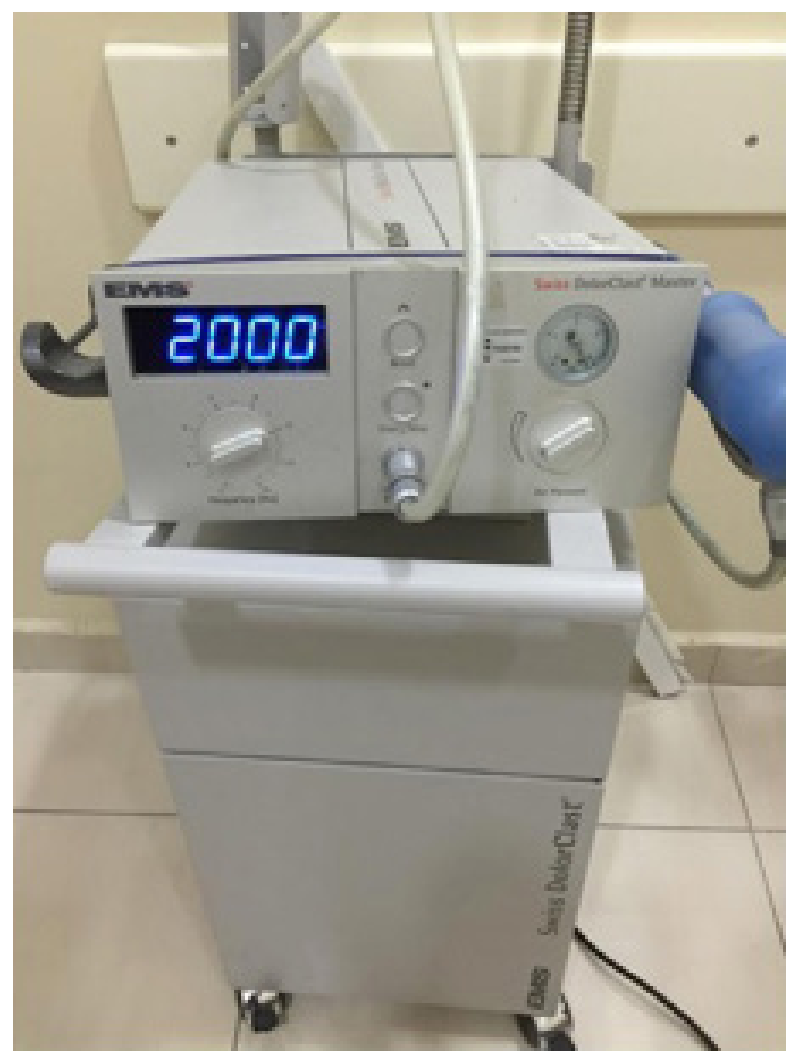

Figure 3. ESWT device. 
Exercises were recommended for 3 days per week, with $8-12$ repetitions.

\section{Exclusion criteria}

Exclusion criteria were the following: systemic comorbidities; space-occupying lesions; recovered or present shoulder instability; a history of surgical operations or injections in the shoulder, neck, or thoracic region; scoliosis greater than 5 degrees; determined kyphosis or other postural disorders; identified herniated disc; a history of major trauma; known allergy against polyacrylate or other substances with a similar structure; past malignancies; active cellulitis, skin irritation, open wounds, deep vein thrombosis or varicosity in the administration area; severe cardiac and psychiatric problems; body mass index levels over 30; acute inflammation and neurologic deficit; complaints concerning both shoulders; and anatomic variations in shoulders.

\section{Assessment}

All patient's visual analogue scale (VAS) scores, special shoulder tests, and the tisabilities of the arm, shoulder and hand (DASH)-T scores were noted, and standardized treatment protocols were queried for a total of three times: at the time of arrival, in the Week 2, and in the Week 4. Shoulder AP and lateral and supraspinatus graphies were requested at the time of arrival and in the Week 4. During this I-month monitoring, no changes were made in the medical treatment of patients. ${ }^{[7]}$

The DASH score is a disability/symptom scale. ${ }^{[8]}$ It can be performed with shoulder anteroposterior and/or supraspinatus graphy.

It is performed with a I.5-Tesla MRI device (Siemens Magnetom Avanto) and standard extremity coil. ${ }^{[8]}$

\section{Statistical analysis}

The IBM-SPSS 22 program was used for the statistical data analysis. Obtained numerical data were represented as the median (minimum-maximum) with descriptive statistics. The confidence interval was assumed at 95\% ( $\alpha=0.05)$. The Kruskal-Wallis test was used for the inter-group analysis of the qualitative data. An exact Wilcoxon twosample test was used to analyze the intra-group pre-treatment and post-treatment differences, and the Freidman test was used for intra-group comparison including more than two-time follow-ups. Frequency tables (number, percentage) were used for descriptive data analysis. For more than two matched exact measurements, the Cochrane $Q$ test was calculated. In all the tests, the Dunn and other multiple comparisons were performed. For quantitative data, a chi-squared test was applied to examine the intergroup distribution. Although all assessment methods were performed bilaterally, only the measurement values of the affected shoulder were included in the statistical analysis. A p-value $<0.05$ was considered statistically significant.

\section{RESULTS}

The average age was $52(22-65)$ in the first group, 5I (2565 ) in second group, and 51 (29-65) in the third group. No difference was determined between the groups with regard to age. No difference was determined between the groups with regard to gender $(p=0.815)$. An average BMI score was 24.44. There was no statistically significant difference determined between the groups with regard to BMI.

In the first group, 10 patients $(28.6 \%)$ were single, 21 patients $(60 \%)$ were married, and 4 patients (11.4\%) were widowed. In the second group, 9 patients $(25.7 \%)$ were single, 25 patients (7I.4\%) were married, and I patient (2.9\%) was widowed. In the third group, 27 patients (25.7\%) were single, 68 patients $(64.8 \%)$ were married, and 10 patients (9.5\%) were widowed. There was no difference among the groups in terms of marital status $(p=0.524)$.

In the first group, 23 patients (65\%) were determined to have Type I acromion, 9 patients (25\%) Type 2 acromion, and 3 patients (8\%) Type 3 acromion; in the second group, 26 patients $(74 \%)$ were determined to have Type I acromion, 8 patients (22\%) Type 2 acromion, and I patient (2\%) Type 3 acromion; in the third group, 27 patients (77\%) were determined to have Type I acromion, 7 patients (22\%) Type 2 acromion, and I patient (2\%) Type 3 acromion according to the Biglani classification. ${ }^{[9]}$ There was no difference with regard to the acromion types $(p=0.7)$ (Fig. 4).

All groups were examined according to the resting VAS (RVAS), movement VAS (MVAS), and night VAS (NVAS) (median [minimum-maximum]). In tables, $\mathrm{P}^{*}$ represents the $p$-value in intra-group comparisons. A significance value of $p<0.00$ I was assumed. Significant values between assessments were indicated in the last column. A significant $p$ value was $<0.05$ in pairwise comparisons (Table I-3).

\section{DASH performance}

No statistically significant difference was determined among intra-group assessments at the time of arrival, and Week 2 and Week 4 dash performance assessment for the Groups I, 2, and $3(p=0.265, p=0.074$, and $p=0.346$, respectively).

\section{DASH disability}

When the disability score measurements taken at the time of arrival and Week 2 and Week 4 were compared for Group I, a statistically significant difference was de-

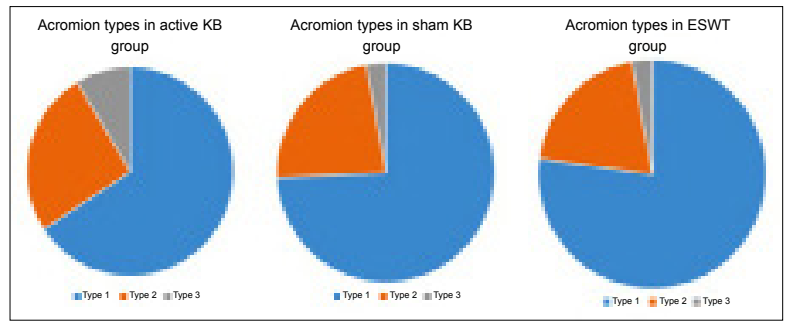

Figure 4. Acromion type distributions of the groups. 
Table I. Examination of Group I with regard to VAS

\begin{tabular}{llllll}
\hline Variable & \multicolumn{2}{c}{ Group I (median follow-up) } & \multicolumn{1}{c}{$\mathbf{p}^{*}$} & \multicolumn{1}{l}{ Pairwise (p<0.05) } \\
\hline RVAS (med [min-max]) & $5(2-8)$ & $3(I-7)$ & $3(I-6)$ & $<0.00 I$ & Arrival (0) vs week 2; Arrival (0) vs week 4 \\
MVAS (med [min-max]) & $5(3-9)$ & $4(0-7)$ & $3(0-6)$ & $<0.00$ I & Arrival (0) vs week 2; Arrival (0) vs week 4 \\
NVAS (med [min-max]) & $2(0-9)$ & I (0-6) & I $(0-3)$ & $<0.00 I$ & Arrival (0) vs week 2; Arrival (0) vs week 4 \\
\hline
\end{tabular}

VAS: Visual Analogue Scale; RVAS: Resting Visual Analogue Scale; MVAS: Movement Visual Analogue Scale; NVAS: Night Visual Analogue Scale.

Table 2. Examination of Group 2 with regard to VAS

\begin{tabular}{llllll}
\hline Variable & \multicolumn{2}{c}{ Group 2 (median follow-up) } & p* & Pairwise (p<0.05) \\
\hline RVAS (med [min-max]) & $5(3-8)$ & $3(I-7)$ & $3(I-6)$ & $<0.00 I$ & Arrival (0) vs week 2; Arrival (0) vs week 4 \\
MVAS (med [min-max]) & $5(3-9)$ & $5(2-8)$ & $4(2-8)$ & $<0.00 I$ & Arrival (0) vs week 2; Arrival (0) vs week 4 \\
NVAS (med [min-max]) & $2(0-4)$ & $2(0-4)$ & $2(0-4)$ & 0.026 & Arrival (0) vs week 2; Arrival (0) vs week 4 \\
\hline
\end{tabular}

VAS: Visual Analogue Scale; RVAS: Resting Visual Analogue Scale; MVAS: Movement Visual Analogue Scale; NVAS: Night Visual Analogue Scale.

Table 3. Examination of Group 3 with regard to VAS

\begin{tabular}{llllll}
\hline Variable & \multicolumn{2}{c}{ Group 3 (median follow-up) } & \multicolumn{1}{c}{$\mathbf{p}^{*}$} & Pairwise (p<0.05) \\
\hline RVAS (med [min-max]) & $4(I-9)$ & $3(I-7)$ & $2(I-6)$ & $<0.00 I$ & Arrival (0) vs week 2; Arrival (0) vs week 4 \\
MVAS (med [min-max]) & $5(2-9)$ & $4(0-6)$ & $3(0-6)$ & $<0.00$ I & Arrival (0) vs week 2; Arrival (0) vs week 4 \\
NVAS (med [min-max]) & $3(0-6)$ & $2(0-5)$ & $1(0-3)$ & $<0.00 I$ & Arrival (0) vs week 2; Arrival (0) vs week 4 \\
\hline
\end{tabular}

VAS: Visual Analogue Scale; RVAS: Resting Visual Analogue Scale; MVAS: Movement Visual Analogue Scale; NVAS: Night Visual Analogue Scale.

termined between the time of arrival and Week 4 dash disability scores. Also, a statistically significant difference was determined between the time of arrival and Week 4 dash disability scores $(p<0.00 \mathrm{I})$.

When the disability score measurements taken at the time of arrival and Week 2 and Week 4 were compared for Group 3, a statistically significant difference was found between the time of arrival and Week 4 dash disabilities. Also, there was a prominent improvement between the first arrival dash scores and Week 2 dash scores $(p<0.001)$.

There was a functionality improvement between the first arrival dash scores and Week 4 in Groups I and 3.

\section{DISCUSSION}

KT applied in the SIS treatment has been reported to provide improvement in early-stage VAS scores and increase the range of motion. ${ }^{[3,4]}$ In our study, we have found that the active KT for SIS treatment lead to a decrease in resting VAS scores, movement VAS scores, and night VAS scores in the 4-week therapy period. However, there are no long-term results due to the fact that our study included only a 4-week follow-up.

Although there are studies in the literature that show the efficacy of ESWT in the treatment of pain, there are also studies showing that it is ineffective. ${ }^{[10,11]}$ We found that
ESWT had a positive effect in pain treatment. Our results showed that ESWT provided a decrease in resting VAS, movement VAS, and night VAS scores, in addition to increasing the joint range of motion and functionality.

Morrison and Bigliani's study carried out in patients with shoulder problems showed a hooked acromion in $80 \%$ and curved acromion in $20 \%$ of the patients with rotator cuff tears. ${ }^{[2]}$ Supraspinatus muscle causes the hooked acromion by the narrowing in the coracoacromial arch, and if there are acromial protrusions, it causes tendon impingement at the acromion anterior. ${ }^{[13-15]}$ There was no difference among the groups with regard to the acromion types; therefore, we concluded that the presence of different acromion types did not affect the safety of our study.

$\mathrm{KT}$ could be used in rehabilitation programs for SIS and rotator cuff tendinitis. They are both decreasing in edema and pain and increasing in the range of motion, and the muscle activity is targeted. KT has shown that it reduces pain in early stages of SIS and increases the range of motion. ${ }^{[16]}$ Decreasing of pain with KT has been explained by means of reduced edema, activating gate control mechanism, and regulating fascia functions. ${ }^{[17]}$ In the long-term studies, it was shown that the positive effects of KT on pain were temporary. ${ }^{[18,19]}$ Although there is strong evidence in the literature about the positive effects of ESWT in SIS, the use of ESWT in non-calcific tendinitis is still controversial. Meta-analyses have shown that the ESWT 
administration in calcific tendinitis leads to decreasing VAS scores. ${ }^{[20]}$ In our study, a clinical improvement similar to the calcific tendinitis was demonstrated with the ESWT application in non-calcific tendinitis.

Haake et al. ${ }^{[21]}$ have applied ESWT in two sessions, at 2000 pulses and $0.35 \mathrm{mj} / \mathrm{mm}^{2}$, to a group including 60 cases with chronic supraspinatus tendinitis; and three sessions, at 2000 pulses and $0.08-0.14 \mathrm{mj} / \mathrm{mm}^{2}$, to the other group. The authors found improved functions in both groups. ${ }^{[2]}$ There is no generally accepted session duration and frequency for tendinitis; however, the numbers are close, and the effects are similar.

In another study performed by Santamato et al., ${ }^{[23]}$ a better improvement in functionality and a greater decrease in pain and increase in muscle endurance were determined with a combination of ESWT and isokinetic exercises in patients with SIS when compared to ESWT alone. With all these data, our study reveals the clinical benefit of KT and ESWT in the treatment of non-calcific tendinitis.

The present study establishes a path for future studies that are going to examine long-term results of the KT and ESWT usage in SIS treatment.

Long-term, controlled, well-designed studies are required to guide the use of ESWT and KT methods, alone or in a combination with other conservative methods, on solid evidence for SIS and non-calcific tendinitis.

In the future, this study should be repeated with long-term follow-up results on a larger sample, which is important in terms of generality of the results of this study.

Ethics Committee Approval

Approved by the local ethics committee.

Informed Consent

Prospective study.

Peer-review

Internally peer-reviewed.

Authorship Contributions

Concept: M.K., B.Ü., Y.K., T.A.; Design: M.K., B.Ü., Y.K., T.A.; Data collection \&/or processing: B.Ü.; Analysis and/ or interpretation: M.K.; Literature search: T.A.; Writing: M.K.; Critical review: M.K.

Conflict of Interest

None declared.

\section{REFERENCES}

1. Oguz H, Çakırbay H, Yanık B. Tıbbı Rehabilitasyon. İstanbul: Nobel; 2015. p. 914.

2. Neer CS. Shoulder Reconstruction. Philadelphia: WB Saunders; 1990.

3. Hsu YH, Chen WY, Lin HC, Wanga WT, Shih YF. The effects of taping on scapular kinematics and impingement syndrome. J Electromyogr Kinesiol 2009;19:1092-9. [CrossRef]

4. Kaya E, Zinnuroglu M, Tugcu I. Kinesio taping compared to physical therapy modalities for the treatment of shoulder impingement syn- drome. Clin Rheumatol 2011;30:201-7. [CrossRef]

5. Rebuzzi E, Coletti N, Schiavetti S, Giusto F. Arthroscopy surgery versus shock wave therapy for chronic calcifying tendinitis of the shoulder. J Orthopaed Traumatol 2008;9:179-85. [CrossRef]

6. Cosentino R, De Stefano R, Selvi E, Frati E, Manca S, Frediani B, et al. Extracorporeal shock wave therapy for chronic calcific tendinitis of the shoulder: single blind study. Ann Rheum Dis 2003;62:248-50.

7. Düger T, Yakut E, Öksüz Ç. The Reliability and Validity of Turkish Version of DASH Questionnaire. Physiothre Rehabil 2006;17:99107.

8. Gerber C. Integrated Scoring Systems for the Functional Assessment of the Shoulder. In: Matsen F, Fu F, Hawkins, editors. The Shoulder: A Balance of Mobility and Stability. New Jersey: Rosemon; 1992. p. 531-50.

9. Bigliani LU, Ticker JB, Flatow EL, Soslowsky LJ, Mow VC. The relationship of acromial architecture to rotator cuff disease. Clin Sports Med 1991;10:823-38.

10. Orhan Z, Ozturan K, Guven A, Cam K. The effect of extracorporeal shock waves on a rat model of injury to tendo Achillis. J Bone Joint Surg 2004;86:613-8. [CrossRef]

11. Mouzopoulos G, Stamatakos M, Mouzopoulos D, Tzurbakis M. Extracorporeal shock wave treatment for shoulder calcific tendonitis: a systemic review. Skeletal Radiol 2007;36:803-11. [CrossRef]

12. Gagey N, Ravaud E, Lassau JP. Anatomy of the acromial arch. Correlation of anatomy and magnetic resonance imaging. Surg Radiol Anat 1993;15:63-70. [CrossRef]

13. Morrison DS, Bigliani LU. The clinical significance of variation in acromial morphology. Orthop Trans 1987;11:234.

14. Saupe N, Pfirrmann CW, Schmid MR, Jost B, Werner CML, Zanetti M. Association between rotator cuff abnormalities and reduced acromio-humeral distance. AJR Am J Roentgenol 2006;187:376-82.

15. Graichen H, Bonel H, Stammberger T, Englmeier KH, Reiser M, Eckstein F. Subacromial space width changes during abduction and rotation, a 3- DMRimaging study. Surg Radiol Anat 1999;21:5964. [CrossRef]

16. Thigpen CA, Padua DA, Morgan N, Kreps C, Karas SG. Scapular kinematics during supraspinatus rehabilitation exercise a comparison of full-can versus empty-can techniques. Am J Sports Med 2006;34:644-52. [CrossRef]

17. Kalichman L, Vered E, Volchek L. Relieving symptoms of meralgia paresthetica using kinesio taping: A pilot study. Arch Phys Med Rehabil 2010;91:1137-9. [CrossRef]

18. Thelen MD, Dauber JA, Stoneman PD. The clinical efficacy of Kinesio tape for shoulder pain: a randomized, double-blinded, clinical trial. J Orthop Sports Phys Ther 2008;38:389-96. [CrossRef]

19. Gonzalez-Iglesias J, Fernandez-de-Las-Penas C, Cleland JA, Huijbregts P, Del Rosario Gutiérrez-Vega M. Shortterm effects of cervical Kinesio taping on pain and cervical range of motion in patients with acute whiplash injury: a randomized clinical trial. J Orthop Sports Phys Ther 2009;39:515-22. [CrossRef]

20. Arirachakaran A, Boonard M, Yamaphai S, Prommahachai A, Kesprayura S, Kongtharvonskul J. Extracorporeal shock wave therapy, ultrasound-guided percutaneous lavage, corticosteroid injection and combined treatment for the treatment of rotator cuff calcific tendinopathy: a network meta-analysis of RCTs. Eur J Orthop Surg Traumatol 2017;27:381-90. [CrossRef]

21. Haake M, Rautmann M, Wirth T. Extracorporeal shock wave therapy vs surgical treatment in calcifing tendinitis and non calcifying tendinitis of the supraspinatus muscle. Eur J Orthop Surg Traumatol 2001;11:21-4. [CrossRef]

22. Chung B, Wiley JP. Extracorporeal shockwave therapy a review. Sports Med 2002;32:851-65. [CrossRef] 
23. Santamato A, Panza F, Notarnicola A, Cassatella G, Fortunato F, de Sanctis JL, et al. Is Extracorporeal Shockwave Therapy Combined with Isokinetic Exercise More Effective Than Extracorporeal
Shockwave Therapy Alone for Subacromial Impingement Syndrome? A Randomized Clinical Trial. J Orthop Sports Phys Ther 2016;46:714-25. [CrossRef]

\section{Subakromiyal Sıkışma Sendromu Tedavisinde Kinezyo Bantlama ve Ekstrakorporeal Şok Dalgası Tedavisinin Kaşılaştııılması}

Amaç: Bu çalışmanın amacı, subakromiyal sıkışma sendromunun tedavisinde kinezyo bantlama (Kinesio taping - KT) ve ekstrakorporeal şok dalga tedavisi (ESWT) yöntemlerinin etkilerini incelemek ve karşılaştırmaktır.

Gereç ve Yöntem: Bu çalışmada subakromiyal sıkışma sendromu olan 105 hasta randomize olarak üç gruba ayrıldı: Aktif Kinezyo bantlama (Grup I), sham kinesiyoloji bantlama (Grup 2) ve ekstrakorporeal şok dalga tedavisi (Grup 3). Hastaların ağrısını ölçmek için Vizuel Analog Skala (VAS) skoru ve fonksiyonel bozuklukların derecesini değerlendirmek için DASH skoru kullanıldı.

Bulgular: Yaş, cinsiyet, medeni hal, vücut kitle indeksi ve akromiyon tipleri açısından gruplar arasında istatistiksel olarak anlamlı bir fark saptanmadı. Grup I ve 3'ün tedavi sonrası VAS skorları başlangıç VAS skorlarına göre düşük saptandı.

Sonuç: Sonuç olarak çalışmamız, kalsifik olmayan tendinit tedavisinde KT ve ESWT kullanımının klinik yararını ortaya koymaktadır. Kısa süreli sonuçlara göre her iki yötem de konservatif tedavilere alternatif olarak önerilebilir.

Anahtar Sözcükler: Ekstrakorporeal şok dalgası tedavisi; kinezyo bantlama; sukakromiyal sıkışma sendromu. 